\title{
The effects of chitosan, sodium lactate and sodium diacetate on the shelf life of hot smoked and vacuum packed rainbow trout fillets
}

\author{
Ceren YAĞIN ${ }^{1}$, Sadık BÜYÜKYÖRÜK ${ }^{2}$ \\ ${ }^{1}$ Adnan Menderes University, Health Science Institute, Department of Food Hygiene and Technology; ${ }^{2}$ Adnan Menderes University, \\ Faculty of Veterinary Medicine, Department of Food Hygiene and Technology, Aydın, Turkey.
}

\begin{abstract}
Summary: This study aims to determine the shelf life of hot smoked and vacuum packed rainbow trout fillets after the application of chitosan, sodium lactate and sodium diacetate. In the study, control group, and rainbow trout fillet sample groups (average weight $100-120 \mathrm{~g}$ ) each processed with $2 \%$ chitosan, $2 \%$ sodium lactate and $0.2 \%$ sodium diacetate. Each group containing 20 samples, were examined in plate count agar for total mesophilic and psychrophilic microorganisms. Total volatile basic nitrogen (TVB-N) and $\mathrm{pH}$ values were also determined. As a result, the shelf life of trout fillets was extended by the use of consumable additives used in the process, particularly chitosan.

Keywords: Chitosan, rainbow trout, shelf life, sodium diacetate, sodium lactate.
\end{abstract}

\section{Sıcak dumanlanmış ve vakum paketlenmiş gökkuşağı alabalık filetolarına uygulanan kitosan, sodyum laktat ve sodyum diasetat' in raf ömrüne olan etkisi}

Özet: Bu çalışma, sıcak dumanlanmış ve vakum paketlenmiş gökkuşağı alabalık filetolarına uygulanan kitosan, sodyum laktat ve sodyum diasetat işlemlerinden sonra bu ürünlerin raf ömürlerini belirlemek amacıyla yapılmıştır. Çalışmada, kontrol grubuna ait 20 örnek ile 20 'şer adet $\% 2$ kitosan, $\% 2$ sodyum laktat ve $\% 0,2$ sodyum diasetat ile işlem görmüş alabalık fileto örnekleri (ortalama 100$120 \mathrm{~g}$ ), toplam mezofilik ve psikrofilik canlılar için plate count agarda incelendi. Aynı zamanda toplam uçucu bazik azot (TVB-N) ve pH değerleri belirlendi. Sonuç olarak, başta kitosan olmak üzere uygulamada kullanılan tüketilebilir katkı maddeleri etkisi ile balık filetolarının raf ömürleri uzatılabilmiştir.

Anahtar sözcükler: Gökkuşağı alabalığı, kitosan, raf ömrü, sodyum diasetat, sodyum laktat.

\section{Introduction}

Fish products, especially those produced from fish and fish meat, have a greater importance than other animal products in today's market in terms of both health properties and their fast perishable characteristics. For a maximum benefit, these products must be consumed in a short time or delivered to the consumers in the best possible quality by storing them in optimum conditions after being caught (38). Additionally, due to high quality consumer food demands, products without chemical preservatives will not be as appealing. Studies move forward in the direction of the extending shelf life of products by using natural food preservatives (7). Chitosan is one of the new generation of additives, and is an important preservative on which research is being conducted today (32). Due to its lack of toxicity, antibacterial and antioxidant characteristics, the formation of a film layer on foods and its biodegradability, chitosan is widely used as a food preservative (19). In order to maintain the microbiological safety and increased shelf life of the foods, organic acids and their derivatives are indicated as natural alternatives $(10,18)$. Lactic acid and its salts, lactates are prominently suggested for food additives which extend shelf life. The safety of food which must be a prime consideration is due to the highly effective microbiological properties that result in no health risks for consumers and does not change the sensory properties of the products (18). Today, in the decontamination of foods ready for use, the addition of sodium lactate is allowed up to $4.8 \%$ and sodium diacetate is sanctioned up to $0.25 \%$ (14).

This study aims to determine the shelf lives of hot smoked and vacuum packed rainbow trout by using chitosan, sodium lactate and sodium diacetate.

\section{Materials and Methods}

Microbiological examinations: For the preparation of chitosan (minimum $85 \%$ degree of deacetylation, Sigma-Aldrich) used in the study, $20 \mathrm{~g}$ chitosan was added to $900 \mathrm{~mL}$ distilled water in order to prepare $2 \%$ chitosan 
solution in $1 \%$ acetic acid. This mixture was stirred for 10 minutes and $10 \mathrm{~mL}$ acetic acid was added to the mixture and stirred overnight with a magnetic stirrer. The next morning the mixture was completed to $1000 \mathrm{~mL}$ with distilled water.

The study consisted of control group, and rainbow trout fillet sample (average weight 100-120 g) groups processed with $2 \%$ chitosan, $2 \%$ sodium lactate and $2 \%$ sodium diacetate. Each study group contained 20 samples of fish, which were provided by a manufacturing company in Aydin/Bozdogan. The trout fillets were kept in the chitosan solution mentioned above, in $2 \%$ sodium lactate and $0.2 \%$ sodium diacetate for 1 minute and were subjected to smoking process at $71^{\circ} \mathrm{C}$ for 25 minutes. Following the smoking process, fillets were vacuum packed and taken to storage containment at $-18^{\circ} \mathrm{C}$. These fillet samples were brought to the laboratory the next day in cold chain for weighing. The vacuum packed, smoked fillets that were selected for the study were randomly taken from the refrigerator at $+4^{\circ} \mathrm{C}$. Following the weighing of the samples, no other sample was taken from the same trout. For subsequent microbiological analyses, the selection of trout fillet samples were also done randomly. During this time, samples were kept in storage at $+4^{\circ} \mathrm{C}$. For the analyses, $25 \mathrm{~g}$ samples were rapidly weighed and homogenized in $225 \mathrm{~mL}$ peptone salt solution $(0.85 \%$ salt $+0.1 \%$ peptone $)$ for 2 minutes. Tenfold serial dilutions were prepared from these homogenized samples $\left(10^{-1}-10^{-6}\right)$ and inoculated in the related media according to pour plate method. Smoked and vacuum packed trout fillet samples from control group, $2 \%$ chitosan, $2 \%$ sodium lactate and $0.2 \%$ sodium diacetate processed groups were inoculated to Plate Count Agar (Oxoid CM325) on day $0,3^{\text {rd }}, 5^{\text {th }}, 12^{\text {th }}, 14^{\text {th }}, 16^{\text {th }}, 18^{\text {th }}$, $20^{\text {th }}, 22^{\text {nd }}$ and $24^{\text {th }}$ days. The resulting inoculations were left in incubation at $35^{\circ} \mathrm{C}$ (mesophilic) for 48 hours and 4 ${ }^{\circ} \mathrm{C}$ (psychrophilic) for 7 days (12).

Total volatile basic nitrogen (TVB-N) determination: $10 \mathrm{~g}$ samples homogenized with applied method were taken to Kjeldahl tubes. Then $2 \mathrm{~g} \mathrm{MgO}$ and $100 \mathrm{~mL}$ distilled water were added to the sample. $100 \mathrm{~mL}$ water and $10 \mathrm{ml} \mathrm{3 \%}$ boric acid and 7-8 drops of Tashiro's indicator were added to $250 \mathrm{~mL}$ flasks. Then, the tube and the flask were placed in Kjeldahl device and distillation was carried out until $200 \mathrm{~mL}$ distillate is obtained in the flask. The obtained distillate was titrated with $0.1 \mathrm{~N} \mathrm{HCl}$ until the solution turned pink to indicate a change in $\mathrm{pH}$. The calculation of TVB-N amount was conducted according to the following formula (4).

Formula: Calculation of the amount of TVB-N

TVB-N mg $/ 100 \mathrm{~g}=\underline{\text { The amount of consumed } 0.1 \mathrm{~N} \mathrm{HCl}(\mathrm{ml}) \times 1.4 \times 100}$ The amount of sample (g)

pH analysis: $\mathrm{pH}$ changes in fish meat was determined according to Soares et al. (33) and the analysis was conducted by using a digital $\mathrm{pH}$ meter. Accordingly, a $5 \mathrm{~g}$ fish sample was taken and stirred in $50 \mathrm{~mL}$ purified water for 30 seconds. $\mathrm{pH}$ meter was dipped into the solution and $\mathrm{pH}$ value of the fish sample was measured.

\section{Results}

In order to extend the shelf lives of smoked and vacuum packed rainbow trout fillets, $2 \%$ chitosan, $2 \%$ sodium lactate and $0.2 \%$ sodium diacetate trials were conducted and the related microbiological results are given in Table 1 and Table 2. Also, regarding the chemical analyses of these fillets, $\mathrm{pH}$ and TVB-N results are given in Tables 3 and 4 .

Table 1. The effects of chitosan, sodium lactate and sodium diacetate applied to the smoked and vacuum packed rainbow trout fillets on the microbiological quality for Total Mesophilic Counts (TMC).

Tablo 1. Dumanlanmış ve vakum paketlenmiş Gökkuşağı alabalık filetolarına uygulanan kitosan, sodyum laktat ve sodyum diasetatın muhafaza süreleri boyunca Toplam Mezofilik Canlı (TMC) sayısına etkileri.

\begin{tabular}{|c|c|c|c|c|c|c|c|c|c|c|c|c|}
\hline \multirow{2}{*}{ Application } & \multicolumn{11}{|c|}{ Storage Time (days) } & \multirow[b]{2}{*}{$26^{\mathrm{a}}$} \\
\hline & $0^{\mathrm{a}}$ & $3^{\mathrm{a}}$ & $6^{\mathrm{a}}$ & $9^{a}$ & $12^{\mathrm{a}}$ & $14^{\mathrm{a}}$ & $16^{\mathrm{a}}$ & $18^{\mathrm{a}}$ & $20^{\mathrm{a}}$ & $22^{\mathrm{a}}$ & $24^{\mathrm{a}}$ & \\
\hline Control Group & 2.70 & 3.68 & 4.32 & 4.98 & 6.32 & 6.99 & 7.58 & & & & & \\
\hline $2 \%$ Chitosan & 2.54 & 3.07 & 3.72 & 3.99 & 4.34 & 4.72 & 5.04 & 5.38 & 5.84 & 6.16 & 6.68 & 7.07 \\
\hline $2 \%$ Sodium lactate & 2.62 & 3.20 & 3.85 & 4.26 & 4.58 & 4.98 & 5.44 & 5.88 & 6.72 & 7.04 & ANC & \\
\hline $0.2 \%$ Sodium diacetate & 2.68 & 3.64 & 4.12 & 4.70 & 5.38 & 5.72 & 6.18 & 6.84 & 7.02 & ANC & & \\
\hline
\end{tabular}

a: $\log 10 \mathrm{cfu} \mathrm{g}^{-1}$ (colony forming unit, per gram).

a: $\log 10 \mathrm{kob} \mathrm{g}^{-1}$ (koloni oluşturan birim, gramda).

ANC: Analiz Yapılmadi.

ANC: Analysis Not Conducted. 
Table 2. The effects of chitosan, sodium lactate and sodium diacetate applied to the smoked and vacuum packed rainbow trout fillets on the microbiological quality for Total Psychrophylic Counts (TPC).

Tablo 2. Dumanlanmış ve vakum paketlenmiş Gökkuşağı alabalık filetolarına uygulanan kitosan, sodyum laktat ve sodyum diasetatın muhafaza süreleri boyunca Toplam Psikrofilik Canlı (TPC) sayısına etkileri.

\begin{tabular}{lccccccccccccc}
\hline \multicolumn{1}{c}{ Application } & \multicolumn{10}{c}{ Storage Time (days) } \\
\cline { 2 - 13 } & $0^{\mathrm{a}}$ & $3^{\mathrm{a}}$ & $6^{\mathrm{a}}$ & $9^{\mathrm{a}}$ & $12^{\mathrm{a}}$ & $14^{\mathrm{a}}$ & $16^{\mathrm{a}}$ & $18^{\mathrm{a}}$ & $20^{\mathrm{a}}$ & $22^{\mathrm{a}}$ & $24^{\mathrm{a}}$ & $26^{\mathrm{a}}$ \\
\hline Control Group & 2.68 & 3.94 & 4.92 & 5.78 & 6.82 & 7.64 & & & & & \\
2\% Chitosan & 2.74 & 3.27 & 4.02 & 4.32 & 4.58 & 4.92 & 5.34 & 5.88 & 6.34 & 6.76 & 7.28 & ANC \\
$2 \%$ Sodium lactate & 2.60 & 3.50 & 3.92 & 4.48 & 4.96 & 5.42 & 6.02 & 6.68 & 7.24 & ANC & \\
$0.2 \%$ Sodium diacetate & 2.68 & 3.84 & 4.42 & 4.96 & 5.62 & 6.02 & 6.54 & 6.94 & 7.42 & ANC & \\
\hline
\end{tabular}

a: $\log 10 \mathrm{cfu} \mathrm{g}^{-1}$ (colony forming unit, per gram).

a: $\log 10 \mathrm{kob} \mathrm{g}^{-1}$ (koloni oluşturan birim, gramda).

ANC: Analiz Yapılmadi.

ANC: Analysis Not Conducted.

Table 3. The effects of chitosan, sodium lactate and sodium diacetate on the TVB-N values of smoked and vacuum packed rainbow trout fillets.

Tablo 3. Dumanlanmış ve vakum paketlenmiş Gökkuşağı alabalık filetolarına uygulanan kitosan, sodyum laktat ve sodyum diasetatın TVB-N sayılarına olan etkisi.

\begin{tabular}{lcccccccccccc}
\hline \multirow{1}{*}{\multicolumn{1}{c}{ Application }} & \multicolumn{10}{c}{ Storage Time (days) } \\
\cline { 2 - 13 } & $0^{\mathrm{a}}$ & $3^{\mathrm{a}}$ & $6^{\mathrm{a}}$ & $9^{\mathrm{a}}$ & $12^{\mathrm{a}}$ & $14^{\mathrm{a}}$ & $16^{\mathrm{a}}$ & $18^{\mathrm{a}}$ & $20^{\mathrm{a}}$ & $22^{\mathrm{a}}$ & $24^{\mathrm{a}}$ & $26^{\mathrm{a}}$ \\
\hline Control Group & 8.43 & 11.9 & 14.2 & 19.8 & 23.8 & 29.4 & & & & & \\
2\% Chitosan & 8.43 & 9.22 & 9.96 & 12.3 & 14.8 & 16.3 & 18.2 & 19.4 & 21.1 & 23.6 & 27.1 & 30.0 \\
2\% Sodium lactate & 8.43 & 9.50 & 10.9 & 14.4 & 17.6 & 20.2 & 23.0 & 26.8 & 29.8 & 32.4 & \\
$0.2 \%$ Sodium diacetate & 8.43 & 9.80 & 12.2 & 14.9 & 17.2 & 19.0 & 22.4 & 26.9 & 30.2 & 34.1 & \\
\hline
\end{tabular}

a: $\mathrm{mg}$ TVB-N/100g

Table 4. The effects of chitosan, sodium lactate and sodium diacetate on the $\mathrm{pH}$ values of smoked and vacuum packed rainbow trout fillets.

Tablo 4. Dumanlanmış ve vakum paketlenmiş Gökkuşağı alabalık filetolarına uygulanan kitosan, sodyum laktat ve sodyum diasetatın pH üzerine olan etkisi.

\begin{tabular}{|c|c|c|c|c|c|c|c|c|c|c|c|c|}
\hline \multirow{2}{*}{ Application } & \multicolumn{12}{|c|}{ Storage Time (days) } \\
\hline & 0 & 3 & 6 & 9 & 12 & 14 & 16 & 18 & 20 & 22 & 24 & 26 \\
\hline Control Group & 5.98 & 5.90 & 6.18 & 6.20 & 6.46 & 6.94 & & & & & & \\
\hline $2 \%$ Chitosan & 5.97 & 5.95 & 6.04 & 6.09 & 6.14 & 6.20 & 6.29 & 6.33 & 6.39 & 6.48 & 6.56 & 6.89 \\
\hline $2 \%$ Sodium lactate & 5.98 & 5.92 & 6.12 & 6.17 & 6.23 & 6.28 & 6.41 & 6.49 & 6.55 & 6.68 & & \\
\hline $0.2 \%$ Sodium diacetate & 5.98 & 5.92 & 6.12 & 6.21 & 6.26 & 6.30 & 6.39 & 6.49 & 6.56 & 6.80 & & \\
\hline
\end{tabular}

\section{Discussion and Conclusion}

As a result of the analyses conducted with the addition of chitosan, sodium lactate and sodium diacetate, smoked and vacuum packed rainbow trout fillets, the total mesophilic aerobic counts (TMC), total psychrophilic counts (TPC) in the control group at the beginning of the trials were 2.70 and $2.58 \log 10 \mathrm{cfu} / \mathrm{g}$, respectively. TMC counts exceeded $7.00 \log 10 \mathrm{cfu} / \mathrm{g}$ on the $14^{\text {th }}$ and $16^{\text {th }}$ days which is the 'best before' date for fish products. TPC count was $7.64 \log 10 \mathrm{cfu} / \mathrm{g}$ on the $14^{\text {th }}$ day. TMC count in $2 \%$ chitosan test samples exceeded this limit level on the $26^{\text {th }}$ day. For $2 \%$ sodium lactate and $0.2 \%$ sodium diacetate, the limit levels were surpassed by the $22^{\text {nd }}$ and the $20^{\text {th }}$ days, respectively. Limit levels for TPC counts in $2 \%$ chitosan, $2 \%$ sodium lactate and $0.2 \%$ sodium diacetate applications were surpassed on the $24^{\text {th }}, 20^{\text {th }}$ and $20^{\text {th }}$ days, respectively. The chitosan, sodium lactate and sodium diacetate levels used in this study, similar to levels applied in previous studies $(20,22,31,35)$ have been preferred.

Sodium salts of the low molecular weight organic acids; such as acetic, lactic, and citric have been used to control microbial growth, improve sensory attributes and extend the shelf life of various foods. In addition to their suppressing effect on the growth of food spoilage bacteria, 
organic salts of sodium acetate, lactate, and citrate were shown to possess antibacterial activities against various food-borne pathogens including Staphylococcus aureus, Yersinia enterocolitica, Listeria monocytogenes, Escherichia coli, as well as Clostridium botulinum. Besides this, these salts are also widely available, economical, and generally "recognized-as-safe" (GRAS) (31).

TMC and TPC counts, are of prime importance for maintaining quality of food consumption in addition to the determination of shelf life. Mohan et al. (23) coated sardine fish with $1 \%$ and $2 \%$ chitosan and stored them at $2{ }^{\circ} \mathrm{C}$ for 12 days and found the TMC counts in samples coated with $1 \%$ chitosan $7.6 \log 10 \mathrm{cfu} / \mathrm{g}$ and in samples coated with $2 \%$ chitosan $7.3 \log 10 \mathrm{cfu} / \mathrm{g}$ at the $11^{\text {th }}$ day. Fan et al. (13), coated the carp fillets with $3 \%$ chitosan and stored at $-3^{\circ} \mathrm{C}$. At the end of $30^{\text {th }}$ day, TMC counts in the application group were below the specified value. Duan et al. (12) coated lingcod (Ophiodon elongatus) fillets, which is a commercial fish species found in North American Pacific, with chitosan and stored the samples. This study yielded TPC counts in excess of $7 \log 10 \mathrm{cfu} / \mathrm{g}$ in the $3^{\text {rd }}$ week and reached $7.5 \log 10 \mathrm{cfu} / \mathrm{g}$ in control group samples at the end of the $1^{\text {st }}$ week. The increase in TMC and/or TPC counts during shelf life were reported by many researchers $(3,8,26,33,34)$. Bacterial growth in our study was inhibited with chitosan, sodium lactate and sodium diacetate which have antimicrobial activities and extended the shelf life of trout fillets up to 24 days without compromising quality of product or taste. Hisar et al. (16) examined the microbiological (psychrotrophic, mesophilic aerobic bacteria and Enterobacteriacae counts) and chemical effects (pH, TVB-N, TBA) of normal atmosphere (control), vacuum packaging and packaging under modified conditions containing gas mixtures (100 CO2\%, $2.5 \% \mathrm{O} 2+7.5 \% \mathrm{~N} 2+90 \% \mathrm{CO} 2$ and $30 \% \mathrm{O} 2+30 \% \mathrm{~N} 2+$ $40 \% \quad \mathrm{CO} 2$ ) at $4 \pm 1{ }^{\circ} \mathrm{C}$ on rainbow trout fillets. Psychrotrophic bacterial counts in samples stored in $10 \%$ $\mathrm{CO}_{2}$ exceeded $7 \log 10 \mathrm{cfu} / \log$ by the $12^{\text {th }}$ day of storage. However, mesophilic bacterial counts reached $6 \log \mathrm{cfu} / \mathrm{g}$ at the end of the storage time (14 ${ }^{\text {th }}$ day).

TVB-N value is a freshness indicator for all fish and fish products whereby TVB-N value increases with degradation of product. In the determination of quality of the fish, Connell (9) limited the TVB-N value to $35-40 \mathrm{mg}$ TVB-N/100 g, while Hisar et al. (16) limited this value to $25 \mathrm{mg}$ TVB-N/100 g in rainbow trout. Varlık et al. (36) evaluated the quality classification in TVB-N values as; "very good" up to $25 \mathrm{mg} / 100 \mathrm{~g}$, "good" up to $30 \mathrm{mg} / 100$ $\mathrm{g}$, "marketable" up to $35 \mathrm{mg} / 100 \mathrm{~g}$ and "spoiled" for more than $35 \mathrm{mg} / 100 \mathrm{~g}$. Also the researchers stated that the consumable limit value for TVB-N value in freshwater fish as $32-36 \mathrm{mg} / 100 \mathrm{~g}$. According to Pezeshk et al. (27), TVB-N primarily consists of trimethylamine, dimethylamine, ammonia and other volatile basic nitrogen compounds. TVB-N is one of the main fish quality index markers and an increase in TVB-N value can occur due to the activity of the microorganisms that cause degradation and endogenous enzymes (30). Changes in TVB-N values in our samples during analyses are given in Table 3. TVB$\mathrm{N}$ value on day 0 in control group, $2 \%$ chitosan, $2 \%$ sodium lactate and $0.2 \%$ sodium diacetate applied group was $8.43 \mathrm{mg} / 100 \mathrm{~g}$, while this value on the $14^{\text {th }}$ day was $29.4 \mathrm{mg} / 100 \mathrm{~g}$ in control group, $30.0 \mathrm{mg} / 100 \mathrm{~g}$ in $2 \%$ chitosan applied group on the $26^{\text {th }}$ day, $32.4 \mathrm{mg} / 100 \mathrm{~g}$ in $2 \%$ sodium lactate applied group on the $22^{\text {nd }}$ day and 34.1 $\mathrm{mg} / 100 \mathrm{~g}$ in $0.2 \%$ sodium diacetate applied group on the $22^{\text {nd }}$ day. The initial TVB-N value determined on day 0 was lower than those reported in some studies $(12,15,24$, 28, 29). Jeon et al. (17), reported $35-50 \%$ decrease in TVB-N formation in morina fish coated with chitosan at the end of 12 days of storage. For sardine fillets that were frozen at $-18{ }^{\circ} \mathrm{C}$ and stored for 6 months, Ozbay and Ayas (26) reported that $19.39 \mathrm{mg} / 100 \mathrm{~g}$ initial TVB-N values increased during storage and reached to $33.24 \mathrm{mg} / 100 \mathrm{~g}$, $29.41 \mathrm{mg} / 100 \mathrm{~g}$ and $27.81 \mathrm{mg} / 100 \mathrm{~g}$ in control, acetic acid and chitosan groups, respectively. Comparing the TVB-N values of all groups, TVB-N value of the chitosan group was found to be lower compared to all other groups.

Sodium lactate (E325) and sodium diacetate (E262) are additives that are used in foods for their beneficial properties such as extending shelf life and improving the aroma properties. In the literature, there are studies in recent years for the extension of the shelf lives of fish products, mostly on chitosan, whereas the studies on sodium lactate and sodium diacetate are very limited. Some researchers have explained that the preservative action relied on two main principles as inhibiting microorganism growth by reducing the water activity, and the specific effect of the lactate ions $(18,37)$. Cetin and Bostan (11), in their study on 'ready to serve' fish balls, found the average water activity in control group samples 0.978 , while the water activity in $2 \%$ sodium lactate added samples was 0.903. Oksuztepe et al. (25) reported that the sensory properties (color, odor and taste) of fish balls prepared from fresh rainbow trout were not affected by using sodium lactate, however it reduced the microbial growth and increased the shelf life. Additionally of $2 \%$ sodium lactate caused no unwanted changes in the sensory properties of the product. Also, it was observed that $2 \%$ sodium lactate added samples maintained their edible properties for 16 days at $4 \pm 1^{\circ} \mathrm{C}$. It was reported that the shelf life increased from 6 days to 16 days.

Alak et al. (1) in their study on determining the effects of chitosan coating or modified atmosphere packaging and vacuum packaging at $4 \pm 1{ }^{\circ} \mathrm{C}$ for 15 days on the microbiological and chemical $(\mathrm{pH}, \mathrm{TVB}-\mathrm{N}$ and 
TBARS) properties of stored bonito fillets, found that the aerobic bacterial growth in fillets coated with chitosan was slower than those of control and vacuum packed groups. The lowest $\mathrm{pH}$ value in all groups were determined in samples coated with chitosan.

$\mathrm{pH}$ measurements were slightly lower than the results found on the $1^{\text {st }}$ day and increasingly higher in the analyses carried out on subsequent days. The average initial value was 5.98 and this value first decreased in all groups and increased in the following days of the storage. $\mathrm{pH}$ range of the fish varied between 5.7 and $6.6 \mathrm{pH}$ value of the fresh fish is close to neutral. However, $\mathrm{pH}$ decreases after death due to the formation of lactic acid and increases again with the start of degradation (5). In this study, the results of $\mathrm{pH}$ measurements following the $1^{\text {st }}$ day analyses were slightly lower than the results of the $1^{\text {st }}$ day, however the analysis results in the following days were increasingly higher. The average initial value was 5.98 and this value first decreased in all groups and increased in the following days of the storage. Similarly, this was also observed by some researchers $(2,6,13,21)$. The decrease in fish samples in the initial results was associated with the increase in soluble $\mathrm{CO}_{2}$ and the subsequent increase in $\mathrm{pH}$ was associated with the increase in volatile bases (TVBN) (6). Mohan et al. (23) found the $\mathrm{pH}$ values in sardine fish coated with $2 \%$ chitosan and stored in the cold as 6.1 on day 0 and 6.6 at the $11^{\text {th }}$ day.

The average storage time of chitosan, sodium lactate and sodium diacetate added, smoked and vacuum packed rainbow trout fillets was extended from the original of 1415 days up to $24-26$ days. This type is stored at $-18^{\circ} \mathrm{C}$ while the satisfactory expiry time for the products that are stored at $+4^{\circ} \mathrm{C}$ before offered to marketing is 18 days. This period was extended with these applications. According to the data obtained in this study, chitosan showed better results in terms of extending shelf life compared to sodium lactate and sodium diacetate.

\section{Acknowledgements}

This study was supported by Adnan Menderes University Scientific Research and Projects as Project No. VTF-13030.

\section{References}

1. Alak G, Hisar SA, Hisar O, et al. (2010): Microbiological and chemical properties of bonito fish (Sarda sarda) fillets packaged with chitosan film, modified atmosphere and vacuum. J Fac Vet Med Kafkas Univ, 16, 73-80.

2. Alasalvar C, Taylor KDA, Oksuz A, et al. (2001): Freshness assessment of cultured seabream (Sparus aurata) by chemical, physical, and sensory methods. Food Chem, 72, 33-40.

3. Angis S. Oguzhan P (2013): Effect of thyme essential oil and packaging treatments on chemical and microbiological properties of fresh rainbow trout (Oncorhynchus mykiss) fillets during storage at refrigerator temperatures. Afr $\mathbf{J}$ Microbiol Res, 7, 1136-1143.

4. Antonocopoulus N (1973): Bestmmung des flüchhtigen basensticktoofs. 224-225. In: Ludorf W, Meyer V (Eds), Fische und fischerzeugnisse. 1th ed. Aulage Verlag Paul Parey Press, Berlin und Hamburg.

5. Bilgin S (2003): Changes on the chemical composition of mountain trout (Salmo trutta macrostigma, Dumeril 1858) by different processing methods. MSc, Suleyman Demirel University, Isparta, Turkey.

6. Can PO, Patir B (2012): Effect of chitosan coatings on the shelf life of rainbow trout (Oncorhynchus mykiss, W. 1792) fillets. J Turk Microbiol Soc, 42, 148-154.

7. Chamanara V, Shabanpour B, Gorgin S, et al. (2012): An investigation on characteristics of rainbow trout coated using chitosan assisted with thyme essential oil. Int J Biol Macromol, 50, 540-544.

8. Chytiri S, Chouliara I, Savvaidis IN, et al. (2004): Microbiological, chemical and sensory assessment of iced whole and filleted aqua cultured rainbow trout. Food Microbiol, 21, 157-165.

9. Connel JJ (1990): Methods of Assessing and Selecting for Quality, in Control of Fish Quality. 3rd ed. Springer, Berlin.

10. Cubina I (1995): Natural lactic acid $L(+)$ and lactates in the food industry. $5^{\text {th }}$ International Congress on Food Industry New Aspects on Food Processing. 106-108, Kusadasi, Turkey.

11. Çetin B, Bostan K (2002): Effect of the sodium lactate on the microbiological quality and shelf life of ready-to-eat meatballs. Turk J Vet Anim Sci, 26, 843-848.

12. Duan J, Cherian G, Zhao Y (2010): Quality enhancement in fresh and frozen lingcod (Ophiodon elongates) fillets by employment of fish oil incorporated chitosan coatings. Food Chem, 119, 524-532.

13. Fan W, Sun J, Chen Y, et al. (2009): Effects of chitosan coating on quality and shelf life of silver carp during frozen storage. Food Chem, 115, 66-70.

14. FDA: Food and Drug Administration (2000): Code of Federal Regulations. http://www.fsis.usda.gov/_OPPDE/ rdad/FRPubs/99-028DF.htm.

15. Frangos L, Pyrgotou N, Giatrakou V, et al. (2010): Combined effects of salting, oregano oil and vacuumpackaging on the shelflife of refrigerated trout fillets. Food Microbiol, 27, 115-121.

16. Hisar SA, Hisar O, Kaya M, et al. (2004): Effects of modified atmosphere and vacuum packaging on microbiological and chemical properties of rainbow trout (Oncorhynchus mykiss) fillets. Int J Food Microbiol, 97, 209-214.

17. Jeon YJ, Kamil JYVA, Shahidi F (2002): Chitosan as an edible invisible film for quality preservation of herring and Atlantic cod. J Agri Food Chem, 20, 5167-5178.

18. Koos JT (1992): Preservation of food products with natural ingredients. Food Mark Technol, 3, 5-11.

19. Majeti NV, Ravi KA (2000): Review of chitin and chitosan applications. React Funct Polym, 46, 1-27.

20. Maks N, Zhu L, Juneja VK, et al. (2010): Sodium lactate, sodium diacetate and pediocin: Effects and interactions on the thermal inactivation of Listeria monocytogenes on bologna. Food Microbiol, 27, 64-69. 
21. Manju S, Jose L, Srinivasa Gopal TK, et al. (2007): Effects of sodium acetate dip treatment and vacuumpackaging on chemical, microbiological, textural and sensory changes of pearlspot (Etroplus suratensis) during chill storage. Food Chem, 102, 27-35.

22. Mbandi E, Shelef LA (2001): Enhanced inhibition of Listeria monocytogenes and salmonella enteritidis in meat by combinations of sodium lactate and diacetate. $\mathrm{J}$ Food Protect, 5, 640-644.

23. Mohan CO, Ravishankar CN, Lalitha KV, et al. (2012): Effect of chitosan edible coating on the quality of double filleted Indian oil sardine (Sardinella longiceps) during chilled storage. Food Hydrocolloid, 26, 167-174.

24. Neratzaki A, Tsiotsias A, Paleologos EK, et al. (2005): Effect of ozonation on the preservation of whole vacuum packaged, refrigerated rainbow trout. Eur Food Res Technol, 221, 675-683.

25. Oksuztepe G, Çoban OE, Güran S (2010): The effect of addition of sodium lactate in fish balls made fromfresh rainbow trout (oncorhynchus mykiss w.). J Fac Vet Med Kafkas Univ, 16, 65-72.

26. Ozbay T, Ayas D (2011): The effects of the use of chitosan and asetic acid on the quality of frozen sardine fillets (Sardinella aurita, Valenciennes, 1847). J Eğirdir Fisheries Fac, 7, 11-22.

27. Pezeshk S, Rezaei M, Hosseini H (2011): Effects of turmeric, shallot extracts and their combination on quality characteristics of vacuum-packaged rainbow trout stored at $4 \pm 1{ }^{\circ} \mathrm{C}$. J Food Sci, 76, 387-391.

28. Pyrgotou N, Giatrakou V, Ntzimani A, et al. (2010): Quality assessment of salted, modified atmosphere packaged rainbow trout under treatment with oregano essential oil. $\mathrm{J}$ Food Sci, 75, 406-411.

29. Rezaei M, Hosseini SF (2005): Quality assessment of farmed rainbow trout (Oncorhynchus mykiss) during chilled storage. J Food Sci, 73, 93-96.

30. Ruiz-Capillas C, Moral A (2005): Sensory and biochemical aspects of quality of whole bigeye tuna (Thunnus obesus) during bulk storage in controlled atmospheres. Food Chem, 8, 347-354.
31. Sallam KI (2007): Antimicrobial and antioxidant effects of sodium acetate, sodium lactate, and sodium citrate in refrigerated sliced salmon. Food Cont, 18, 566-575.

32. Shahidi F, Arachchi JKV, Jeon YJ (1999): Food applications of chitin and chitosan. Trends Food Sci Technol, 10, 37-51.

33. Soares NM, Mendes TS, Vicente AA (2013): Effect of chitosan-based solutions applied as edible coatings and water glazing on frozen salmon preservation - A pilot-scale study. J Food Engin, 119, 316-323.

34. Song Y, Liu L, Shen H, et al. (2010): Effect of sodium alginate-based edible coating containing different antioxidants on quality and shelf life of refrigerated bream (Megalobrama amblycephala). Food Cont, 22, 608-615.

35. Stekelenburg FK, Kant-Muermans MLT (2001): Effects of sodium lactate and other additives in a cooked ham product on sensory quality and development of a strain of Lactobacillus curvatus and Listeria monocytogenes. Int $\mathbf{J}$ Food Microbiol, 66, 197-203.

36. Varlik C, Baygar T, Ozden O, et al. (2000): Sensory evaluation and determination of some physical and chemical characteristics of shrimp (parapenaeus longirostris, lucas 1846) during cold storage. Turkish J Vet Anim Sci, 24, 181185.

37. Wit De JC, Rombouts FM (1990): Antimicrobial activity of sodium lactate. Food Microbiol, 7, 113-120.

38. Yıldırım O, Ergun S, Yaman S, et al. (2005): Effects of two seaweeds (Ulva lactuca and Enteromorpha linza) as a feed additive in diets on growth performance, feed utilization, and body composition of rainbow trout (Oncorhynchus mykiss). J Fac Vet Med Kafkas Univ, 15, 455-460.

Geliş tarihi: 27.08.2015 / Kabul tarihi: 25.03.2016
Address for correspondence:
Assist. Prof. Sadik BUYUKYORUK, PhD, DVM
Adnan Menderes University,
Faculty of Veterinary Medicine,
Department of Food Hygiene and Technology,
09016, Isikli, Aydin,Turkey.
e-mail: sbuyukyoruk@adu.edu.tr 